\title{
China (Shanghai) Pilot Free Trade Zone Investor-State Dispute Settlement: An Uncertain Experiment
}

\author{
Gonzalo Villalta Puig* \\ The University of Hull \\ g.villalta.puig@hull.ac.uk \\ Leung Tsam Tai ${ }^{* *}$ \\ Eversheds Sutherland (Hong Kong)
}

\begin{abstract}
The China (Shanghai) Pilot Free Trade Zone (PFTZ) is the first free trade zone of the People's Republic of China (PRC). It seeks to reform the national economy and open it up to foreign investment. This article argues that the suite of legal instruments that establish the PFTZ - the Framework Plan, the Negative List, the Decision, and the Management Method - are legally uncertain and that their legal uncertainty could cause disputes between PFTZ investors and the PRC. To address the problem of legal uncertainty, the article proposes, first, the adoption of a rational connection to the PFTZ as the test for jurisdiction of the PFTZ Court and the PFTZ Court of Arbitration; secondly, the enactment of the Negative List and the Decision as laws in order to clarify their legal status; and, thirdly, a reform of the PFTZ dispute settlement mechanism under the Management Method into an arbitral system.
\end{abstract}

\section{Keywords}

foreign investment law - China (Shanghai) Pilot Free Trade Zone - investor-state disputes

\section{Introduction}

The China (Shanghai) Pilot Free Trade Zone (PFTZ) is one of the biggest steps towards economic reform that the government of the People's Republic of China (PRC) has taken in recent years. It builds on the Special Economic Zones (SEZs) set up by the State Council in the 1980s. The SEZs in Shenzhen, Zhuhai, Shantou, Xiamen, and Hainan ${ }^{1}$ aim to attract 'foreign investment, advanced technology, managerial expertise and to increase employment'. ${ }^{2}$ To achieve these aims, SEZs offer different incentives, such as the removal of tariffs on imported goods for re-export ${ }^{3}$ and the reduction of corporate profits tax on joint ventures from 33 per cent to 15 per cent. ${ }^{4}$ The aims of the PFTZ, however, are much more ambitious: the PRC government envisions it as a testing ground for

\footnotetext{
* Gonzalo Villalta Puig is Head of the School of Law and Politics and Professor of Law at The University of Hull, where he holds the established Chair in the Law of Economic Integration. Professor Villalta Puig is an Overseas Fellow of the Australian Academy of Law and a Fellow of the European Law Institute. He is chair of the Research Group for Constitutional Studies of Free Trade and Political Economy of the International Association of Constitutional Law and a member of the Committee on the Procedure of International Courts and Tribunals and the former Committee on International Trade Law and Study Group on Preferential Trade Agreements of the International Law Association. Professor Villalta Puig is a member of the Full Council of the International Law Association. He is Associate Editor of the Global Journal of Comparative Law (Brill Nijhoff). Professor Villalta Puig is Outstanding Fellow of the Faculty of Law at The Chinese University of Hong Kong.

** Sabrina Leung Tsam Tai is a Trainee Solicitor with Eversheds Sutherland (Hong Kong). She writes in a personal capacity.

${ }^{1}$ Hu Jiaxiang, 'Shanghai Free Trade Pilot Zone, The Model for Future China?' Working Paper Series No 35 (Asian Law Institute, 2014) 3.

2 Anne Fenwick, ‘Evaluating Chins’ Special Economic Zones’ (1984) 2(2) Berkeley JIL 377.

${ }^{3}$ Giovanni Palmioli \& Adam Heal, 'Structural Economic Reform in China: The Role of the Shanghai Free Trade Zone' (2014) 3 Economic and Social Communication for Asia and the Pacific 4.

${ }^{4}$ Fenwick (n 2) 383.
} 
innovative economic policies and reforms which, depending on their performance, may eventually be implemented nationally to liberalise domestic trade and investment.

The PFTZ operates as an exemption from certain PRC market access and customs rules. Unlike free trade zones operating in jurisdictions such as the United Arab Emirates - where the various free zones of Dubai and Abu Dhabi each come under a completely new regime - the PFTZ remains subject to the overall authority of the PRC government, which sets the requisite 'national strategies'. ${ }^{5}$ The close relationship between the PFTZ and the PRC government extends to the subnational level. The PFTZ Management Committee, which administers the management of the PFTZ, serves as the agent ${ }^{6}$ of the Shanghai Municipal People's Government in coordinating and managing the operation of the PFTZ.

Through the use of a negative list approach, a simplified business registration system, loosened control over offshore financing activities, and enhanced Renminbi (RMB) convertibility, the PRC government aims to simplify administrative procedures and create a favourable business environment in the PFTZ. The business opportunities and commercial efficiency brought by these policies are convincing more and more multinational companies that the PFTZ is the ideal pad from which to launch their products for the PRC. ${ }^{7}$ More than 30,000 companies have already been set up inside the PFTZ since its establishment in $2013 .{ }^{8}$ This early success has encouraged the PRC government to extend many of its policies for the PFTZ beyond the PFTZ. In December 2014, the State Council issued a notice ${ }^{9}$ giving national application to selected policies previously only applied inside the PFTZ. In November 2016, the State Council issued another notice giving national application to 19 additional PFTZ policies. ${ }^{10}$

Given the experimental nature of the PFTZ, its policies are inevitably novel. That novelty, whilst attractive, can also cause investors to worry. The Framework Plan, ${ }^{11}$ the Negative List, $^{12}$ the Decision $^{13}$ and the Management Method ${ }^{14}$ are four key legal instruments under which innovative

$$
5 \text { State Council, “国务院关于 印发中国( 上海 ) }
$$

自由贸易试验区总体方案的通知 [No 38] (Framework Plan for the China (Shanghai) Pilot Free Trade Zone)’ (27 September 2013).

${ }^{6}$ Shanghai Municipal People’s Government, ‘中国（上海）自由贸易试验区管理办法 [No 7] (Management Method of the China (Shanghai) Pilot Free Trade Zone)’ (9 September 2013).

${ }^{7}$ Xinhua, 'Xinhua Insight: China’s Free Trade Zones Pilot Reforms for Efficiency and Openness' (Xinhuanet.com, 21 April 2016) <http://news.xinhuanet.com/english/2016-04/21/c_135301365.htm> accessed 30 January 2017.

${ }^{8}$ Korean International Trade Association, 'Pilot Free Trade Zones Are Popular as Investment Destination in China' (2016) <http://kita.org/about/newsView.do?id=\&no=1927\&searchWrd=\&result_url=> accessed 30 January 2017.

${ }^{9}$ State Council, ‘国务院关于推广中国(上海)自由贸易试验区可复制改革试点经验的通知 [No 65] (Notice of the State Council on the Wide_Application of Replicable Reform Experience from the Pilot Programs in China (Shanghai) Pilot Free Trade Zone)’ (21 December 2014).

10 State Council, ‘国务院关于做好自由贸易试验区新一批改革试点经验复制推广工作的通知 [No 63] (Notice of the State Council on the Further_Application of Replicable Reform Experience from the Pilot Programs in China (Shanghai) Pilot Free Trade Zone)’’ (2 November 2016).

${ }^{11}$ State Council (n 5).

${ }^{12}$ Shanghai Municipal People’s Government, ‘中国 ( 上海) 自由贸易试验区外商投资准入特别管理措施 (负面清

单 ) ( 2013 年) [No 75] (Special Administrative Measures on Foreign Investment Access to the China (Shanghai) Pilot Free Trade Zone (2013)' (29 September 2013).

${ }^{13}$ Standing Committee of the National People’s Congress of the People’s Republic of China, ‘全国人大常委会关于授 权国务院在中国(广东)自由贸易试验区、中国(天津)自由贸易试验区、中国(福建)自由贸易试验区以及中国(上 海)自由贸易试验区扩展区域暂时调整有关法律规定的行政审批的决定 (Decision of the Standing Committee of the National People's Congress on Authorizing the State Council to Temporarily Adjust the Relevant Administrative Approval Items Prescribed by Law in the China (Guangdong) Pilot Free Trade Zone, the China (Tianjin) Pilot Free 
policies are introduced to the PFTZ. The uncertainty over the legal status and duration of these instruments as well as the associated ambiguity with which they manage the settlement of investment disputes - whether private-private or investor-state - and the review of investor related decisions by the PFTZ Management Committee could all give rise to disputes between PFTZ investors and the PRC.

The PFTZ has not adopted sufficient preventive measures and resolution mechanisms to ensure the effective settlement of potential disputes arising from the uncertainty and ambiguity of its experimental policies. In order to explore the further steps that the PFTZ needs to take if it is to sustain its long-term development, this article discusses the possible causes of investor-state disputes with reference to a number of legal instruments key to the implementation of preferential policies inside the PFTZ. An interpretative analysis of the PFTZ's Framework Plan and related legal instruments reveals legal uncertainty to be a potentially significant cause of disputes between PFTZ investors and the PRC. The article proposes solutions to the problems of legal uncertainty. Through a study of the PRC's legal system, the PFTZ's functioning, and foreign practice, the article presents an assessment of both the threats that the PFTZ is facing with the Framework Plan (see Section 3.1), the Negative List (see Section 3.2), the Decision (see Section 3.3), and the Management Method (see Section 3.4); as well as the opportunities available to it to withstand those threats (see Section 4).

\section{Political Economy and Law of the PFTZ}

The PFTZ, launched on 29 September 2013, is the PRC's first free trade zone. The PFTZ, covering an area of about 120 square kilometres, comprises several customs supervision zones: the Waigaoqiao Free Trade Zone, Waigaoqiao Free Trade Logistics Park, Yangshan Free Trade Port Area, Pudong Airport Free Trade Zone, and, as of 1 March 2015, the Lujiazui Financial Area, Jinqiao Export Processing Zone, and Zhangjiang High Tech Park. ${ }^{15}$

The PFTZ was established to further the decision of the Central Committee of the Communist Party of China and the State Council to facilitate the 'reform and opening-up' ${ }^{16}$ of the country. To realise those aims, the PFTZ pursues four key policies: first, to open the service sector; secondly, to facilitate the transformation of government functions; thirdly, to reform the financial sector; and, fourthly, to enhance the convertibility of the RMB. These policies apply to all companies set up inside the PFTZ, without charging any fees or imposing any restrictions on their operations. In other words, there is no hidden price that the PFTZ companies have to pay for benefitting from the significant benefits that come with the PFTZ as an experimental setup.

\subsection{Opening Up the Service Sector}

Aware that a country's economic development is linked to the degree of exposure to competition of its service sector, the PRC's most recent step towards economic reform has taken off with a substantial expansion to the scope of service industries open to foreign investors. The PRC had previously been fairly reluctant to open up its service sector to foreign direct investment (FDI) by categorising service industries into 'encouraged', 'restricted', 'prohibited', and 'permitted' labels

\footnotetext{
Trade Zone, the China (Fujian) Pilot Free Trade Zone, and the Expanded Zone of the China (Shanghai) Pilot Free Trade Zone)' (28 December 2014).

${ }^{14}$ Shanghai Municipal People’s Government (n 6).

${ }^{15}$ China (Shanghai) Free Trade Zone, 'Introduction' (2016) <http://en.china-shftz.gov.cn/About-FTZ/Introduction/> accessed 30 January 2017; State Council, ‘China’s External Debt Stands at \$1.68 trillion in June’ (2 October 2015) <http://english.gov.cn/archive/statistics/2015/10/02/content_281475202939874.htm> accessed 30 January 2017.

${ }^{16}$ State Council (n 5) pt 1.
} 
under the Catalogue for the Guidance of Foreign Investment ${ }^{17}$ (the Catalogue), which is applied nationally to all foreign investors who wish to conduct business activities inside the PRC. The Services Trade Restrictive Index, published by the Organisation for Economic Co-operation and Development (OECD) in May 2014, compared the degree of restrictions on international trade and investment across 18 service industries in the PRC with 40 other countries, including the OECD member states, Brazil, Russia, India, Indonesia, and South Africa. The study revealed that the PRC displays a relatively high level of restrictiveness, particularly in service industries labelled 'restricted' and 'prohibited', which are traditionally dominated by State Owned Enterprises (SOEs), such as commercial banking, insurance and air transport services. ${ }^{18}$

Hence, expanding the scope of service industries for FDI has been one of the major strategies of the PFTZ, particularly in financial services, shipping services, commercial trade services, professional services, cultural services, and social services. ${ }^{19}$ Trade liberalisation largely depends on the effective removal of restrictions on trade in services, which, in turn, depends on the adoption of either a positive or a negative list approach in the Catalogue. A positive list permits only those service industries that are expressly stated on the list whereas a negative list permits all those industries that are not stated on the list. Hence, the negative list approach is often considered to be a more liberal approach. It also creates a 'pro-liberalization dynamic' ${ }^{20}$ as the authorities are likely to shy away from the production of a lengthy negative list.

The PFTZ's unprecedented use of a negative list appears to offer greater market access than the PRC's traditional positive list approach. Prior to the establishment of the PFTZ, foreign investors wishing to establish business in the PRC were required to consult the Catalogue to determine if their investment projects were within the permissible categories of FDI in the PRC. On 30 September 2013, the first version ${ }^{21}$ of the PFTZ Negative List was released by the Shanghai Municipal People's Government to specify the types of FDI that are not permitted in the PFTZ. An amended version of the Negative List was released in $2014,{ }^{22}$ reducing the number of restrictions on the types of FDIs from 190 to 139. The 2015 Negative List further reduced the number of restrictions to $122,{ }^{23}$ with a significant removal of restrictions on conducting business activities concerning the mining industry, ${ }^{24}$ manufacturing industry ${ }^{25}$ as well the wholesale and retail

\footnotetext{
${ }^{17}$ State Development and Reform Commission \& Ministry of Commerce, ‘外商投资产业指导目录(2015 年) [No 22] (Catalogue of Industries for Guiding Foreign Investment (2015 Revision)’ (10 March 2015).

${ }^{18}$ OECD, 'STRI Sector Brief: Insurance' (2014) <www.oecd.org/tad/services-trade/STRI_insurance.pdf> accessed 30 January 2017; OECD, 'STRI Sector Brief: Commercial Banking' (2014) <www.oecd.org/tad/servicestrade/STRI_commercial_banking.pdf> accessed 30 January 2017; OCED, 'STRI Sector Brief: Air Transport Services’ (2014) <www.oecd.org/tad/services-trade/STRI_air_transport_services.pdf> accessed 30 January 2017.

${ }^{19}$ State Council (n 5) pt 2.

${ }^{20}$ Patrick Low and Aaditya Mattoo, 'Is There a Better Way? Alternative Approaches to Liberalization Under the GATS' in Pierre Sauvé and Robert M Stern (eds), GATS 2000: New Directions in Services Trade Liberalization (Brookings Institution Press 2000) 468.

${ }^{21}$ Shanghai Municipal People’s Government, ‘中国(上海)自由贸易试验区外商投资准入特别管理措施(负面清单)

(2013 年) [No 75] (Special Administrative Measures on Foreign Investment Access to the China (Shanghai) Pilot Free Trade Zone (Negative List) (2013)’ (29 September 2013).

${ }^{22}$ Shanghai Municipal People’s Government, ‘中国(上海)自由贸易试验区外商投资准入特别管理措施(负面清单)

(2014 年修訂) [No 1] (Special Administrative Measures on Foreign Investment Access to the China (Shanghai) Pilot Free Trade Zone (Negative List) (2014)’ (30 June 2014).

${ }^{23}$ State Council, ‘国务院办公厅关于印发自由贸易试验区外商投资准入特别管理措施(负面清单)的通知 [No 23]

(Notice of the General Office of the State Council on Issuing the Special Management Measures (Negative List) for Foreign Investment Access in Pilot Free Trade Zones)' (8 April 2015).

${ }^{24}$ ibid, pts 7-14. Given the limited space and resources available inside the PFTZ, the Negative List primarily applies to the research and development divisions of these companies deemed suitable to develop inside the PFTZ.
} 
industry ${ }^{26}$ inside the PFTZ. Restrictions on processing food including rice, ${ }^{27}$ edible oils, ${ }^{28}$ and corn $^{29}$ have been removed. Similar restrictions over alcohol, ${ }^{30}$ tea, ${ }^{31}$ and tobacco ${ }^{32}$ have also been removed. However, restrictions on motor vehicles, aircrafts, and ships remain, each requiring a Chinese investor to take up at least a 50 per cent interest or even a controlling interest in the Foreign-Invested Enterprise (FIE). ${ }^{33}$

\subsection{Facilitating the Transformation of Government Functions}

The adoption of a Negative List has significant implications not only for the liberalisation of foreign investment but also for the transformation of government functions. At present, foreign investors who invest outside the PFTZ are required to go through a time-consuming pre-approval process. First, investors must determine the nature of their proposed investment, that is, whether it would be classified as an 'encouraged', 'permitted', 'restricted', or 'prohibited' ${ }^{34}$ project pursuant to the Catalogue and the Guiding Direction of Foreign Investment Provisions. ${ }^{35}$ Secondly, they must prepare a project application report, ${ }^{36}$ including a feasibility study, for submission to the Development and Reform Commission (DRC), either at the local or national level. Depending on factors such as the total amount of investment and whether there is any restriction on Chinese shareholding, ${ }^{37}$ the application to the DRC, either at the local or national level, may be submitted by either filing (for registration purposes) or verification (which requires the application to be verified and approved by the authorities). ${ }^{38}$ Verification is a more onerous process, as it requires additional legal documents such as a letter of intent, approval documents from the Environment Protection Department, and an energy conservation rating from the Energy Conservation Department. ${ }^{39}$ Even

25 ibid, pts 15-30. Given the limited space and resources available inside the PFTZ, the Negative List primarily applies to the research and development divisions of these companies deemed suitable to develop inside the PFTZ.

26 ibid, pts 37-40.

${ }^{27}$ Shanghai Municipal People’s Government (n 22) pt 21.

28 ibid, pt 22.

29 ibid, pt 24.

30 ibid, pt 25.

31 ibid, pt 26.

32 ibid, pts 27 and 28.

${ }^{33}$ State Council (n 23) pts 7-9.

${ }^{34}$ Guiding Direction of Foreign Investment Provisions (Promulgated by Decree No 346 of the State Council of the People’s Republic of China on 11 February 2002, and effective as of 1 April 2002) art 4.

35 ibid.

${ }^{36}$ State Council, ‘中华人民共和国中外合资经营企业法实施条例 2014 [No 648] (Regulation on the Implementation of the Law of the People’s Republic of China on Chinese-Foreign Equity Joint Ventures 2014)’ (19 February 2014) art 7; State Council, ‘中华人民共和国中外合作经营企业法实施细则 2014 [No 648] (Regulation on the Implementation of the Law of the People's Republic of China on Chinese-Foreign Contractual Joint Ventures 2014)’ (19 February 2014) art 7; State Council, ‘中华人民共和国外资企业法实施细则 2014 [No 648] (Regulation on the Implementation of the PRC Wholly Foreign Owned Enterprises Law 2014)’ (19 February 2014) art 10.

${ }^{37}$ State Development \& Reform Commission, “外商投资项目核准和备案管理办法 2014 [No 12] (Administrative Measures for the Confirmation and Recordation of Foreign-Funded Projects 2014)’ (17 May 2014) art 4; State Development \& Reform Commission, ‘国家发展改革委关于修改《境外投资项目核准和备案管理办法》和《外商

投资项目核准和备案管理办法》有关条款的决定(2014) [No 2] (Decision of the National Development and Reform Commission on Amending the Relevant Clauses of the Measures for the Administration of the Confirmation and Recordation of Overseas Investment Projects and the Measures for the Administration of the Confirmation and Recordation of Foreign-Funded Projects (2014))’ (27 December 2014) art 2(2); State Council, ‘国务院关于发布政府 核准的投资项目目录(2014 年本)的通知 [No 53] (Notice of the State Council on Issuing the Catalogue of Investment Projects Subject to Government Confirmation (2014)) (31 October 2014) art 11.

${ }^{38}$ State Development \& Reform Commission, “外商投资项目核准和备案管理办法 2014 [No 12] (Administrative Measures for the Confirmation and Recordation of Foreign-Funded Projects 2014)’ (17 May 2014) art 3.

39 ibid art 10 . 
after obtaining approval from the local or national DRC, depending on the total amount of the investment, ${ }^{40}$ foreign investors must also obtain approval for the form of FIE business vehicle by submitting a joint venture contract or articles of association to the Commission of Commerce (COFCOM) or Ministry of Commerce (MOFCOM). ${ }^{41}$ After obtaining approval for the establishment of the project and the form of business vehicle, foreign investors must then obtain approval from the State Administration of Industry and Commerce (SAIC) ${ }^{42}$ for the aim and the business scope of the project before a business license can be issued. Importantly, in considering whether approval shall be given, the various authorities involved enjoy a high level of discretion in interpreting the broad criteria set out in the statues, for example, whether the project is in line with national development plans and industrial policies. ${ }^{43}$ These restrictive and complicated procedures have made the setting up of businesses in the PRC a relatively time-consuming exercise for foreign investors.

The adoption of a Negative List inside the PFTZ, by contrast, means that only projects listed are subject to restriction or prohibition and, thus, need a pre-approval procedure. Foreign investors seeking to establish projects that are not mentioned in the list are only required to go through a record-filing procedure with the PFTZ Administrative Commission. To further expedite the setting up of businesses, the PFTZ simplifies this application process by establishing a one-stop application platform. Unlike the existing system that requires investors to submit documents to three different authorities for approval - local or national DRC, COFCOM or MOFCOM and SAIC - the one-stop system adopted in the PFTZ only requires investors to submit all application documents to the Authority for Industry and Commerce (AIC) ${ }^{44}$ for circulation as part of the approval and filing process. The AIC then issues the relevant license and certificates (business license, enterprise code certificate, and tax registration certificate) to the investors. ${ }^{45}$ As a result, while it may take around 29 days to set up a business elsewhere in the PRC, it only takes around four days for a business license to be issued to a PFTZ investor. ${ }^{46}$ The new system also simplifies companies' continuing obligations after incorporation. Companies set up inside the PFTZ are the first to enjoy a simplified

\footnotetext{
${ }^{40}$ State Development \& Reform Commission, “国家发展改革委关于做好外商投资项目下放核准权限工作的通知 2010 [No 914] (Notice of NDRC on Decentralizing the Verification Power for Foreign Investment Projects 2010)’ (4 May 2010) art 11.

${ }^{41}$ State Council, ‘中华人民共和国中外合资经营企业法实施条例 2014 [No 648] (Regulation on the Implementation of the Law of the People’s Republic of China on Chinese-Foreign Equity Joint Ventures 2014)’ (19 February 2014) art 6; State Council, ‘中华人民共和国中外合作经营企业法实施细则 2014 [No 648] (Regulation on the Implementation of the Law of the People's Republic of China on Chinese-Foreign Contractual Joint Ventures 2014)’ (19 February 2014) art 7; State Council, ‘中华人民共和国外资企业法实施细则 2014 [No 648] (Regulation on the Implementation of the PRC Wholly Foreign Owned Enterprises Law 2014)’ (19 February 2014) art 7.

${ }^{42}$ State Council, ‘中华人民共和国中外合资经营企业法实施条例 2014 [No 648] (Regulation on the Implementation of the Law of the People’s Republic of China on Chinese-Foreign Equity Joint Ventures 2014)’ (19 February 2014) art 9; State Council, ‘中华人民共和国中外合作经营企业法实施细则 2014 [No 648] (Regulation on the Implementation of the Law of the People's Republic of China on Chinese-Foreign Contractual Joint Ventures 2014)’ (19 February 2014) art 9; State Council, ‘中华人民共和国外资企业法实施细则 2014 [No 648] (Regulation on the Implementation of the PRC Wholly Foreign Owned Enterprises Law 2014)’ (19 February 2014) art 12.

${ }^{43}$ State Development \& Reform Commission (n 38) arts 16 and 19; State Development \& Reform Commission (n 40) art 7.

${ }^{44}$ Shanghai Administration for Industry and Commerce, “工商总局关于授于上海市工商行政管理局自由贸易试验区

分局外商投资企业登记管理权的通知(Circular of the State Administration for Industry and Commerce on Authorizing the Administrative Authority of Foreign-Invested Enterprises Registration to the Branch of Shanghai Administration for Industry and Commerce in the Free Trade Zone)' (24 September 2013).

45 Yao Lu, 'Establishing a Company in the Shanghai FTZ' (China Briefing, 12 March 2014) <www.chinabriefing.com/news/2014/03/12/establishing-a-company-in-the-shanghai-ftz.html> accessed 30 January 2017.

${ }^{46}$ Giovanni Palmioli \& Adam Heal, 'Structural Economic Reform in China: The Role of the Shanghai Free Trade Zone’ [2014] 3 Trade Insights 6.
} 
reporting regime - to publish information about the business on the AIC's publicly available online platform - and do away with the former system of having an annual inspection. ${ }^{47}$

Furthermore, to realise the PFTZ's aim to facilitate trade liberalisation, major changes have been made to simplify customs procedures and regulations. First, goods entering the PFTZ from outside the PRC by Class B companies ${ }^{48}$ - the status of most newly established companies ${ }^{49}$ - can be declared within ' 14 days' ${ }^{50}$ of entry by completing simple 'filing formalities' 51 instead of the previous 'administrative approval system', ${ }^{2}$ together with a submission of the application form and a copy of the registration certificate. ${ }^{53}$ The post-entry declaration system is further expedited by the provision of an electronic platform to complete filing requirement for air and sea imports ${ }^{54}$ as well.

\subsection{Reforming the Financial Sector}

Given the substantial liberalisation of trade inside the PFTZ across different sectors, there is a need for a comprehensive reform of the financial sector to handle the accompanying increase in crossborder business on financing and trade settlement. Already prior to the establishment of the PFTZ, the PRC government introduced different measures attempting to remedy the weaknesses of its financial system, such as removing the floor on lending rates ${ }^{55}$ as well as reforming banking governance. ${ }^{56}$

Under the PFTZ, various innovative policies have been introduced, one of which allows foreign banks to establish either wholly owned subsidiaries or joint venture banks inside the PFTZ. ${ }^{57}$ Previously, foreign banks were not allowed to do so unless they had set up a representative office

\footnotetext{
${ }^{47}$ Shanghai Administration for Industry and Commerce, “上海市工商行政管理局关于印发《关于中国 (上海 ) 自由 贸易试验区内企业登记管理的规定》的通知 (Shanghai Administration for Industry and Commerce's Notice on Publishing the Regulation on the Management of Registration of Enterprises Inside the China (Shanghai) Free Trade Zone) (30 September 2013) art 14.
}

${ }^{48}$ Shanghai Customs, “上海海关关于在中国 ( 上海 ) 自由贸易试验区实施境外入区货物“先进区、后报关”作业模 式的公告 [No 6] (Announcement of Shanghai Customs on Implementing the Operation Mode of Goods entering the Zone from Abroad by 'First Entering and then Declaring' in China (Shanghai) Pilot Free Trade Zone)' (21 April 2014) art 2(1).

${ }^{49}$ General Administration of Customs of PRC, ‘中华人民共和国海关企业分类管理办法 [No 197] (Measures of the Customs of the People’s Republic of China on the Classified Management of Enterprises)’ (30 November 2011).

50 ibid art 5.

51 ibid art 3.

52 Shanghai Customs, “上海海关关于在中国 ( 上海) 自由贸易试验区内实施企业注册登记改革等事项的公告 [No 28] (Announcement of Shanghai Customs on business registration reform in PFTZ)’ (30 June 2014) art 1.

53 ibid.

${ }^{54}$ Shanghai Customs, “上海海关关于全面实施“放行信息电子化”管理的公告 [No 40] (Announcement of Shanghai Customs on Implementing the Electronic Platform for Shipping and Air Cargo)' (8 October 2014); General Administration of Customs of PRC of Commerce of PRC, ‘海关总署 商务部关于从中国 (上海) 自由贸易试验区 进口的涉及自动进口许可证管理货物开展通关作业无纸化试点的公告 [No 58] (Announcement of the General Administration of Customs and the Ministry of Commerce of PRC on Operating the PFTZ Electronic Platform)' (5 August 2014) art 1.

${ }^{55}$ Wei Liao and Sampawende J-A Tapsoba, 'China’s Monetary Policy and Interest Rate Liberalization: Lessons from International Experiences’ Working Paper Series No 14/75 (International Monetary Fund, 2014) 6 <https://www.imf.org/external/pubs/ft/wp/2014/wp1475.pdf> accessed 30 January 2017.

${ }^{56}$ Didier Cossin \& Abraham Lu, 'The ICBC Path to Chinese Governance: Lessons for the Western and Emerging Markets’ The European Financial Review (December 2012/January 2013) $66<$ https://tinyurl.com/jeyyxpr> accessed 30 January 2017.

${ }^{57}$ Shen Wei, ““A Tale of Three Zones” - Promises and Pitfalls of Three Financial Experimental Zones in China’ [2014] Banking Law Journal 417. 
for a minimum of two years. ${ }^{58}$ Significant changes have also been made to liberalise offshore financing activities. Under the rules introduced by the Shanghai Head Office of the People's Bank of China (PBOC), ${ }^{59}$ qualified participants, including corporate and non-bank financial institutions inside the PFTZ, ${ }^{60}$ are now allowed to obtain offshore financing either in RMB or a foreign currency. ${ }^{61}$ More importantly, the limit on the amount of offshore funds that qualified participants can borrow has now been loosened. First, for FIEs outside the PTFZ, they are allowed to borrow the difference between their total investment amount and their registered capital. ${ }^{62}$ If FIEs need to borrow more than the permissible sum, they need to justify that the additional sum is for purposes envisaged in the bank's business scope. ${ }^{63}$ Additionally, they need to apply for approval to increase the total amount of investment, which involves making the corresponding amendments to the joint venture contract or the articles of association. ${ }^{64}$ Therefore, FIEs need to submit their application to these authorities again before they can borrow the additional sum of money. Domestic enterprises outside the PFTZ are also subject to a limit on the permissible amount of foreign debt, which is to be determined by the State Administration of Foreign Exchange (SAFE) or approved by the State Council within 15 business days after signing the loan agreements. ${ }^{65}$ In contrast, the permissible amount of foreign debt for participants inside the PFTZ is determined by capital, offshore financing leverage ratio and macro adjustment factors. ${ }^{66}$ Companies inside the PFTZ are allowed to borrow

\footnotetext{
${ }^{58}$ State Council, ‘中华人民共和国外资银行管理条例 [No 478] (Regulation of the People's Republic of China on the Administration of Foreign-funded Banks) (11 November 2006 art 10(2). The restriction was subsequently lifted by an amendment made in 2014. Starting 1 January 2015, no foreign banks, whether inside or outside the PFTZ, will be subject to the restriction.

${ }^{59}$ Shanghai Head Office of People’s Bank of China, ‘中国 ( 上海) 自由贸易试验区分账核算业务境外融资 与跨境 资金流动宏观审慎管理实施细则 ( 试行) [No 8] (The Trial Implementation Rules on the Macroscopic Prudent Management of Account-Based Settlement Business for Offshore Financing and Cross-Border Capital Flow in the China (Shanghai) Pilot Free Trade Zone)' (12 February 2015).

60 ibid art 4.

61 ibid art 5 .

${ }^{62}$ State Council, ‘中华人民共和国中外合资经营企业法实施条例 2014 [No 648] (Regulation on the Implementation of the Law of the People’s Republic of China on Chinese-Foreign Equity Joint Ventures 2014)’ (19 February 2014) art 17; State Council, ‘(中华人民共和国中外合作经营企业法实施细则 2014 [No 648] (Regulation on the Implementation of the Law of the People's Republic of China on Chinese-Foreign Contractual Joint Ventures 2014)' (19 February 2014) art 15; State Council, ‘中华人民共和国外资企业法实施细则 2014 [No 648] (Regulation on the Implementation of the PRC Wholly Foreign Owned Enterprises Law 2014)’ (19 February 2014) art 19.

${ }^{63}$ State Council, ‘中华人民共和国中外合资经营企业法实施条例 2014 [No 648] (Regulation on the Implementation of the Law of the People’s Republic of China on Chinese-Foreign Equity Joint Ventures 2014)’ (19 February 2014) art 11; State Council, “中华人民共和国中外合作经营企业法实施细则 2014 [No 648] (Regulation on the Implementation of the Law of the People's Republic of China on Chinese-Foreign Contractual Joint Ventures 2014)' (19 February 2014) art 12; State Council, ‘中华人民共和国外资企业法实施细则 2014 [No 648] (Regulation on the Implementation of the PRC Wholly Foreign Owned Enterprises Law 2014)’ (19 February 2014) art 14.

${ }^{64}$ State Council, ‘中华人民共和国中外合资经营企业法实施条例 2014 [No 648] (Regulation on the Implementation of the Law of the People’s Republic of China on Chinese-Foreign Equity Joint Ventures 2014)’ (19 February 2014) arts 11 and 13; State Council, ‘中华人民共和国中外合作经营企业法实施细则 2014 [No 648] (Regulation on the Implementation of the Law of the People's Republic of China on Chinese-Foreign Contractual Joint Ventures 2014)’ (19 February 2014) arts 12 and 13; State Council, ‘中华人民共和国外资企业法实施细则 2014 [No 648] (Regulation on the Implementation of the PRC Wholly Foreign Owned Enterprises Law 2014)’ (19 February 2014 ) arts 14 and 15.

${ }^{65}$ State Administration of Foreign Exchange, ‘国家外汇管理局关于发布《跨境担保外汇管理规定》的通知 [No 29] (Notice of the State Administration of Foreign Exchange on Issuing the Provisions on the Foreign Exchange Administration of Cross-border Guarantees)' (12 May 2014) app 1, art 9.

${ }^{66}$ Shanghai Head Office of People’s Bank of China (n 59) art 7.
} 
twice their capital whereas non-bank financial institutions are able to borrow two to three times their capital. ${ }^{67}$

This relaxation has a significant implication for investors operating in the PRC since offshore borrowing has become a major source of finance over the years. In June 2015, the PRC had an outstanding foreign debt of around RMB 1.68 trillion. ${ }^{68}$ By February 2015, Chinese companies operating inside the PFTZ had already borrowed RMB 19.7 billion. ${ }^{69}$ Given the tighter control outside the PFTZ, companies sometimes need to set up offshore shell companies to avoid the borrowing limit and the requirement for prior approvals. However, transferring the money for onshore use has often been a cumbersome process for many investors. Corporates and non-bank financial institutions inside the PFTZ may now use foreign funds borrowed for production or operational activities and construction projects both inside the PFTZ and outside the PRC. ${ }^{70}$

The PRC's aim to liberalise trade across the whole country is evident from a circular ${ }^{71}$ published by the PBOC on extending the new rules implemented inside the PFTZ on offshore financing to the three other free trade zones ${ }^{72}$ in the PRC. As of 25 January 2016, twenty-four pilot domestic banks and three pilot foreign invested banks are allowed to conduct offshore financing in either RMB or a foreign currency as long as they comply with new macro prudential policies. The overarching principle of these polices is that the total amount of outstanding debt in RMB and foreign currencies after multiplying the applicable risk (Cross Border Financing Risk Weighted Outstanding) is not more than the Cross Border Financing Risk Weighted Outstanding Upper Limit (Upper Limit). ${ }^{73}$ In order to further facilitate the financing process, this new regime dispenses companies with the need to apply for pre-approval. Pilot companies are only required to file with SAFE after signing the cross-border financing agreement but within three business days before the drawdown. ${ }^{74}$ Also, foreign currencies obtained through cross-border financing can be converted to RMB on actual need provided that they are used for operating the business without violating applicable PRC regulations and policies. ${ }^{75}$ Whereas pilot financial institutions are required to submit the details of the calculation of the Cross Border Financing Risk Weighted Outstanding and the Upper Limit to the PBOC and SAFE before execution of the relevant cross-border financing agreement. ${ }^{76}$ Yet, pilot financial institutions are also allowed to convert foreign currencies borrowed through cross-border financing into RMB upon obtaining SAFE's approval. ${ }^{77}$ More importantly, FIEs can choose to apply either this new rule or any existing applicable rules, ${ }^{78}$ both of which would simplify offshore borrowing procedures for them and enhance flexibility in financing their business activities, including RMB convertibility.

\subsection{Enhancing RMB Convertibility}

\footnotetext{
67 ibid.

${ }^{68}$ State Council (n 15).

${ }^{69}$ Gabriel Wildau, 'Shanghai Free Trade Zone Loosens Curbs on Offshore Borrowing’ (Financial Times, 13 February 2015) <http://www.ft.com/intl/cms/s/0/3bd2056a-b339-11e4-b0d2-00144feab7de.html\#axzz47wHy9RWL> accessed 30 January 17.

${ }^{70}$ Shanghai Head Office of People’s Bank of China (n 59) art 14.

${ }^{71}$ People’s Bank of China, ‘中国人民银行关于扩大全口径跨境融资宏观审慎管理试点的通知 [No 18] (Circular of the People's Bank of China on Expanding the Pilot Program of Prudent Macro Management of Cross-border Financing)' (22 January 2016).

${ }^{72}$ Shanghai Free Trade Zone, Guangdong Free Trade Zone, Tianjin Free Trade Zone and Fujian Free Trade Zone.

${ }^{73}$ People's Bank of China (n 71) art 3.

74 ibid art 10.

75 ibid art 10(4).

76 ibid art 11(3).

77 ibid art 11(4).

78 ibid art 13(4).
} 
Enhancing RMB convertibility has been one of the PFTZ's key strategies to facilitate cross-border capital flow and establish Shanghai as an international financial center. The lack of a flexible exchange rate and an open capital account have presented some of the main hurdles for transforming the RMB into an international currency. Previously, FIEs could only make foreign exchange settlements by providing the authorities with details of the use of the funds and the extent of investment in specific FDI projects. ${ }^{79}$ SAFE would then clarify whether the needs were actual on a case-by-case basis before an approval could be granted. ${ }^{80}$ At present, FIEs operating inside the PFTZ are allowed to open a RMB deposit account 'directly linked with their foreign exchange account'. ${ }^{81}$ FIEs have full discretion in deciding when to make conversions between foreign currencies and RMB without having to specify the use of the funds, except in a few specific circumstances, for example, investing in illegal projects. ${ }^{82}$ Furthermore, the new rules allow overseas financial leasing without first applying for approval.

By enhancing the convertibility of the RMB, the PFTZ is able to handle foreign exchange settlements more effectively and, thus, facilitate the internationalisation of the RMB. The removal of restrictions over interest rates for deposits inside the PFTZ also strengthens the currency's ability to cope with fluctuations in the global market. Starting 1 March 2014, the Shanghai PBOC removed the prescribed maximum interest rate for banks set up inside the PFTZ if the deposit in foreign currencies is less than USD 500,000. ${ }^{83}$ This deregulation enables banks to enjoy greater degree of flexibility in fixing appropriate interest rates according to the demand and supply of foreign currencies in the domestic market as well as competition from neighbouring countries. Ultimately, it allows the PFTZ to lure business opportunities and channel currencies from abroad more effectively.

\section{The Problem of Legal Uncertainty as a Cause of Investment Disputes}

Strategies aside, numerous are the laws and measures that establish the PFTZ. Among those laws and measures, four provide for preferential treatment to foreign investors in the PFTZ (PFTZ investors). First is the Framework Plan, ${ }^{84}$ which details the strategic policies and reforms to be implemented inside the PFTZ. Second is the Negative List, ${ }^{85}$ which details the list of industry sectors that are subject to restriction. Third is the Decision, ${ }^{86}$ which removes the requirement imposed on foreign investors to apply for administrative approvals before making an investment in the PRC as stated in four sets of legal documents. ${ }^{87}$ And fourth is the Management Method, ${ }^{88}$ which

\footnotetext{
${ }^{79}$ Wei (n 57) 419.

80 Regulation of People's Republic of China on Foreign Exchange Administration (2008) art 12 $<$ https://tinyurl.com/hn7pa38> accessed 30 January 2017.

${ }^{81}$ Shanghai Exchange, “国家外汇管理局关于在部分地区开展外商投资企业外汇资本金结汇管理方式改革试点有
}

关问题的通知 [No 36] (Notice of Shanghai Branch of the State Administration of Foreign Exchange on Issuing the Detailed Rules for the Implementation of Regulations on Foreign Exchange Management in the China (Shanghai) Pilot Free Trade Zone)' (4 August 2014) annex, art 2.

82 ibid art 12.

${ }^{83}$ Shanghai Head Office of People’s Bank of China, ‘中国人民银行上海总部关于在中国 ( 上海) 自由贸易试验区

放开小额外币存款利率上限的通知 [No 23] (Circular of the Shanghai Head Office of People's Bank of China on removing the ceiling of interest rate for small-denomination deposits in foreign currencies in the China (Shanghai) Pilot Fee Trade Zone)' (25 February 2014).

${ }^{84}$ State Council (n 5).

${ }^{85}$ Shanghai Municipal People’s Government (n 21).

${ }^{86}$ Standing Committee of the National People’s Congress of the People’s Republic of China (n 13).

${ }^{87}$ State Council, ‘中华人民共和国中外合资经营企业法实施条例 2014 [No 648] (Regulation on the Implementation of the Law of the People's Republic of China on Chinese-Foreign Equity Joint Ventures 2014)’ (19 February 2014); State Council, ‘中华人民共和国中外合作经营企业法实施细则 2014 [No 648] (Regulation on the Implementation of the Law of the People's Republic of China on Chinese-Foreign Contractual Joint Ventures 2014)’ (19 February 2014); 
gives an overview of the relevant legislation and authorities involved in the management of the PFTZ. These legal instruments are exceptional because they promote and protect foreign investment in the PFTZ even though the approach to the regulation of foreign investment market access everywhere else in the PRC is protectionist. Yet, because they are exceptional, they cannot rely on precedent to give them legal certainty. This section of the article explains the uncertainty that characterises the Framework Plan, the Negative List, the Decision, and the Management Method and argues that such uncertainty can cause disputes between PFTZ investors and the PRC.

\subsection{The Framework Plan}

he Framework Plan establishes a tribunal and an arbitration centre for the PFTZ. It defines the scope of their jurisdiction in terms of a connection with the PFTZ. These terms are uncertain. The PFTZ tribunal of the Shanghai Pudong New Area People's Court, including the PFTZ intellectual property tribunal, function as the court of the PFTZ (PFTZ Court), which has jurisdiction to settle private-private disputes 'connected with' ${ }^{89}$ the PFTZ. In parallel, the Shanghai International Economy and Trade Arbitration Commission (also known as the Shanghai International Arbitration Center (SHIAC)) functions as the arbitration centre of the PFTZ (PFTZ Court of Arbitration), ${ }^{90}$ which has jurisdiction to arbitrate ${ }^{91}$ private-private disputes 'connected with' ${ }^{92}$ the PFTZ. Wholly foreign owned enterprises registered within the PFTZ would be allowed to arbitrate their case in a foreign arbitration institution if they have entered into an arbitration agreement that allows for the submission of their disputes to arbitration outside the PRC. ${ }^{93}$ However, for parties intending to take their disputes to the PFTZ Court or the PFTZ Court of Arbitration, the Framework Plan does not state the criteria that determine the degree of connection with the PFTZ necessary for the PFTZ Court and PFTZ Court of Arbitration to have jurisdiction in a case. Such uncertainty can, theoretically speaking, cause both private-private disputes among PFTZ investors and privatepublic disputes between PFTZ investors and the PRC, for example, whether certain cases should be handled by the PFTZ Court or courts outside the PFTZ. Subsequent amendment has failed to clarify this ambiguity. On 27 April 2015, the Shanghai Pudong New Area People's Court announced an extension to the PFTZ Court's scope of jurisdiction commensurate with the expansion of the PFTZ. First, the PFTZ Court is now responsible for handling commercial and intellectual property matters of a civil, criminal or administrative nature that are 'connected with' the four original customs supervision zones formerly comprising the PFTZ. ${ }^{94}$ Secondly, the PFTZ Court is now responsible for handling commercial and intellectual property matters that are 'connected with' either the three newly expanded areas of the PFTZ ${ }^{95}$ or foreign parties, Hong Kong, Taiwan and FIEs in other zones of the Pudong New Area. ${ }^{96}$ Thirdly, based on the PFTZ's own development, the Pudong

State Council, ‘中华人民共和国外资企业法实施细则 2014 [No 648] (Regulation on the Implementation of the PRC Wholly Foreign Owned Enterprises Law 2014)’ (19 February 2014); Standing Committee of the National People’s Congress, ‘中华人民共和国台湾同胞投资保护法 1994 [No 20] (Law of the People’s Republic of China on the Protection of Investments of Taiwan Compatriots 1994)’ (5 March 1994).

${ }^{88}$ Shanghai Municipal People’s Government (n 6).

89 Shanghai FTZ Court, 'Jurisdiction of the PFTZ Court' (2015) <www.ftzcourt.gov.cn:8080/zmqweb/gweb/content.jsp?pa=aaWQ9NjEzMzkmeGg9MQPdcssPdcssz> accessed 30 January 2017.

${ }^{90}$ Shanghai International Arbitration Rules (2014) art 2.

91 ibid art 3. Either upon the 'party's agreement'.

92 ibid.

93 Supreme People’s Court, ‘最高人民法院关于为自由贸易试验区建设提供司法保障的意见 [No 34] (Opinions on Providing Judicial Protection for the Construction of Pilot Free Trade Zones)’ (30 December 2016) art 9(1).

${ }^{94}$ Waigaoqiao Free Trade Zone, Waigaoqiao Free Trade Logistics Park, Yangshan Free Trade Port Area and Pudong Airport Free Trade Zone.

${ }^{95}$ Lujiazui Financial Area, Jinqiao Export Processing Zone, and Zhangjiang High Tech Park.

${ }^{96}$ Shanghai Municipal People’s Government, ‘浦东新区人民法院对自贸区法庭受案范围做相应调整 (The Pudong New Area People's Court Made Adjustments to the PFTZ Court's Scope of Jurisdiction) (2015) 
New Area's economic development and the reform of the government systems, the PFTZ Court shall adjust its scope of jurisdiction accordingly. ${ }^{97}$ Thus, the new rule perpetuates the uncertainty of the former rule by continuing with the use of the generic phrase 'connected with' and giving extensive discretion to the court in deciding whether a case falls into any of the aforesaid areas (Applicable Areas) and should be accepted. Since the PFTZ is a scheme for the PRC to test the viability of a more favourable legal environment for the liberalisation of trade and investment, restrictions on foreign investment applicable elsewhere in the PRC are not applicable in the PFTZ. ${ }^{98}$ This development could potentially lead to a more favourable outcome for PFTZ investors than the likely outcome if their disputes were to come for settlement before a court other than the PFTZ Court or the PFTZ Court of Arbitration. Also, the validity of an award granted by any courts other than the PFTZ Court or the PFTZ Court of Arbitration in the PFTZ may not be guaranteed. Hence, the existing uncertainty may cause disputes among PFTZ investors and or between them and the PRC authorities if PFTZ investors believe their matters are not being handled by the appropriate court as a result of any such uncertainty. Thus, a clear definition of the scope of jurisdiction (that is, the proper venue for handling disputes) could reduce administrative and time costs for both the authorities and investors.

\subsection{The Negative List}

The Negative List extends 'pre-access national treatment' 99 to PFTZ investors. Despite its significance to the promotion and protection of foreign investment in the PFTZ (negative list pilot reform projects have launched elsewhere in the PRC, including Guangdong, Tianjin, and Fujian), the Negative List has an unclear legal status within the current PRC legal structure, which could potentially cause investor-state disputes, as have been observed by certain Chinese legal scholars ${ }^{100}$ and will be discussed below. The latest revised Negative List was announced by the State Council in 2015. ${ }^{101}$ However, the list does not provide details of the authority who enacted the list. It only states - equivocally so - that the list has been made in accordance with 'the relevant laws and regulations currently in force'. ${ }^{102}$ Earlier versions of the Negative List issued in 2013 and 2014 respectively did not offer any clear explanations either. Both versions were announced by the Shanghai Municipal Government, ${ }^{103}$ without specific reference to the relevant enacting authority.

Under the Law of the People's Republic of China on Legislation 2015, valid forms of laws are, first, laws 'enacted and amended' 104 by the National People's Congress (NPC), namely the Constitution of the PRC ${ }^{105}$ and such other Basic Laws, ${ }^{106}$ and, secondly, laws ${ }^{107}$ 'enacted and amended, ${ }^{108}$ by the Standing Committee of the National People's Congress (SCNPC). ${ }^{109}$ Thus, the only government bodies that can exercise 'legislative power of the state' ${ }^{110}$ are the NPC and

\footnotetext{
<www.shanghai.gov.cn/nw2/nw2314/nw32419/nw32510/nw32511/nw32516/u21aw1004339.html> accessed 30 January 2017.

97 ibid.

${ }^{98}$ Standing Committee of the National People’s Congress of the People’s Republic of China (n 13).

99 ibid art 11.

${ }^{100}$ See, for example, Shen Hai Ping, 'The Legal Status and Adjustment of the Negative List of the China (Shanghai)

Pilot Free Trade Zone (上海自贸区的法律地位及其调整)’ [2014] 5 Oriental Law 131.

101 State Council (n 23).

102 ibid art 1.

103 Shanghai Municipal People’s Government (n 22); Shanghai Municipal People’s Government (n 21).

104 PRC Legislation Law (2015) art 7.

105 ibid art 87. With the 'highest legal authority'.

106 ibid art 7.

107 ibid.

108 ibid.

109 ibid. With the exception of laws that can only be enacted by the NPC.

${ }^{110}$ PRC Constitution (2004) art 58; PRC Legislation Law (2015) art 7.
} 
SCNPC. However, the NPC and SCNPC can 'authorise' 111 the State Council to make 'administrative regulations'. ${ }^{112}$ Local People's Congresses and the Standing Committees of Local People's Congresses of a 'province, autonomous region, or municipality' ${ }^{113}$ directly under the PRC government can make 'local regulations' if necessary, ${ }^{114}$ whereas the People's Government of such subnational jurisdictions can make administrative rules for the purposes set out in Article 82 of the Legislation Law.

Therefore, given that the PFTZ is under the administration of the PFTZ Management Committee ${ }^{115}$ instead of the Shanghai Municipal People's Government, the 2013 and 2014 versions of the Negative List announced by the Shanghai Municipal People's Government could not have been enacted as laws. Presumably, the Negative List would have the status either as an administrative regulation or as a local regulation applicable only to the PFTZ. However, even if that presumption were to hold true, such a regulation would not be valid unless either the 'Standing Committee of the Local People's Congress'116 or 'provincial governor, chairman of the autonomous region or mayor of the city' ${ }^{117}$ had enacted it by way of an 'announcement'. ${ }^{118}$ Under the Management Method, which is a local administrative rule released by the Shanghai Municipal People's Government, the Shanghai Municipal People's Government was to 'announce' the Negative List. ${ }^{119}$ Since the PFTZ does not come under the administration of the Shanghai Municipal People's Government, its authority to announce the Negative List for the PFTZ is questionable.

On one argument, the Shanghai Municipal People's Government had authority to announce the Negative List for the PFTZ. After all, under the Framework Plan, the Shanghai Municipal People's Government shall make 'administrative rules for the PFTZ' ${ }^{120}$ through 'local legislation. ${ }^{121}$ This provision could suggest ${ }^{122}$ that the Shanghai Municipal People's Government is acting under the authorisation of the State Council to make laws for the PFTZ, which would, accordingly, give the Negative List legal status as a piece of authorised legislation. In the legal system of the PRC, 'authorised legislation' ${ }^{123}$ refers to a 'legal document' ${ }^{124}$ issued by a body with no legislative power under the authorisation of another body with the requisite legislative power. The Shanghai Municipal People's Government makes authorised legislation from time to time. In 2012, for example, the Standing Committee of Shanghai Municipal People's Congress issued a Decision on Promoting Innovation and Transitional Development in response to a Central Government plan to create a more favourable environment for scientific research in Shanghai. This legal instrument enables the Shanghai Municipal People's Government to make regulations with respect to five matters, namely the 'liberalisation, betterment of the market system, recruitment of talent, creation

\footnotetext{
111 PRC Legislation Law, ibid art 9.

112 ibid art 8. In areas under art 8 for objectives under art 65 of the Legislation Law (2015) except where the NPC or SCNPC have similar regulations.

113 ibid art 72.

114 ibid, unless they conflict with the PRC Constitution, laws or administrative regulations.

115 Shanghai Municipal People’s Government (n 6) art 4.

116 PRC Legislation Law (2015) art 78.

117 ibid art 85.

118 ibid arts 78 and 85.

${ }^{119}$ It is also responsible for 'formulating' the accompanying Management Method for the Approval and Filing of Foreign Investment Items: Shanghai Municipal People’s Government (n 6) art 11.

${ }^{120}$ State Council (n 5) pt 11 (9).

121 ibid.

${ }^{122}$ Liu Hua, 'A Study on the Legal Issues Concerning the China (Shanghai) Pilot Free Trade Zone - Innovative Management, Giving the Green Light and Advance Legislation’ (中国 ( 上海 ) 自由贸易试验区法律问题研究——

管理创新、“法律绿灯”与地方先行立法) [2014] 2 Oriental Law 126.

${ }^{123} \mathrm{Hu}$ Huai and Li Chang Xi, ‘Some Issues on Authorized Legislation (授权立法若干问题研究)’ (2001) 16(5) Journal of Henan University of Economics and Law 58.

124 ibid.
} 
of an entrepreneurial environment and rectification of the existing social exclusion system'. ${ }^{125}$ On this argument, if the Negative List contained similar authorisations for a set of specified goals, it should already have legal status as a piece of authorised legislation.

On another argument, the Negative List does not contain all the necessary details to meet the requirements for a piece of authorised legislation, even in its latest 2015 version. First, the State Council does not have autonomous power to make laws. It can receive authorisation to make administrative regulations on a list of matters ${ }^{126}$ for the purposes ${ }^{127}$ set out in the Legislation Law. However, the design of the Negative List relies not only on adjustments to certain administrative regulations but also on adjustments to four national laws. ${ }^{128}$ Such adjustments are outside the scope of the legislative power of the State Council and, hence, they are also outside the scope of any prospective authorisation that it could give. Secondly, the Legislation Law requires, as the Decision on Promoting Innovation and Transitional Development shows, any piece of authorised legislation to state clearly its of 'objective and scope'. ${ }^{129}$ Such detail is absent from the text of the Negative List. This lack of detail is likely to raise even more difficult issues in the light of the most recent amendment to the Legislation Law. ${ }^{130}$ Further to this amendment, an authorisation shall state essential details such as its 'purpose, subject matter, scope and term of empowerment'; ${ }^{131}$ no authorisation shall exceed 'five years'; and, any request to extend the limitation period of an authorisation shall be made 'six months prior to the expiration' ${ }^{132}$ The amendment suggests that the intention of the Central Government is to limit the use of authorised legislation. Therefore, without an express statement that addresses the requisite details, it is unlikely that the Negative List can acquire legal status as a piece of authorised legislation by either the State Council in its 2015 version or the Shanghai Municipal People’s Government in its 2014 and 2013 versions.

Though the Negative List does not qualify as a piece of authorised legislation, it constitutes a form of Normative Document (ND). NDs are legally binding documents that administrative units issue from time to time in order to 'complement the execution of relevant laws, regulations, rules and policies of the State'. ${ }^{133}$ They are not, however, considered to be a piece of law. Further to the Notice from the Central Office and State Council on publishing the Rules on Handling Official Documents of Party Units, NDs may exist in various forms, such as in the form of an 'order, decision, announcement or notice'. ${ }^{134}$ The Negative List constitutes a ND because, first, it is in the form of an announcement; secondly, the State Council and the Shanghai Municipal People's Government respectively had the authority to announce the Negative List 'in response to decisions

\footnotetext{
125 Shanghai People’s Congress, ‘上海市人大常委会发布关于促进创新驱动、转型发展的决定 [No 50] (Decision on Promoting Innovation and Transitional Development)’ (7 June 2012) art 7.

${ }^{126}$ PRC Legislation Law (2015) art 8.

127 ibid art 65

128 See references in $n 87$.

${ }^{129}$ PRC Legislation Law (2015) art 10.

${ }^{130}$ Shuang Yang, 'Explanation Session on the Approval of the PRC Legislation Law Amendment (Draft) (立法法修正

案 (草 案) 获 通过 赞 成 2761 票 反对 81 票， (China.com, 15 March 2014) <http://news.china.com.cn/2015lianghui/2015-03/15/content_35056802.htm> accessed 30 January 2017.

${ }^{131}$ PRC Legislation Law (2015) art 10.

132 ibid.

${ }^{133}$ Legislative Affairs Office of the State Council (PRC), 'An Analysis of the Basic Procedure on Formulating Other Normative Documents ( 浅 析 制 定 其 他 规范 性 文 件的 一 般程 序) ’ (2011) <http://www.chinalaw.gov.cn/article/dfxx/dffzxx/yn/201102/20110200333341.shtml> accessed 30 January 2017. ${ }^{134}$ Central Office \& State Council, ‘中共中央办公厅、国务院办公厅关于印发《党政机关公文处理工作条例》的
} 通知 [No 14] (Notice from the Central Office and State Council on publishing the Rules on Handling official documents of Party Units)'_(14 April 2012) art 8. 
made by the State's Superior Administrative Unit'; 135 and, thirdly, the Negative List does not have a 'specific target of application' 136 and can apply 'repeatedly' ${ }^{137}$ to the same party. In other words, the Negative List applies however many times a PFTZ investor makes an investment.

The problem is that, although NDs are legally binding, the People's Courts, ${ }^{138}$ including the PFTZ Court, cannot accept disputes related to NDs. They can only adjudicate laws. ${ }^{139}$ And NDs are not laws. In principle, then, PFTZ investors are not able to bring disputes related to the Negative List before the PFTZ Court. In practice, however, the courts do occasionally accept disputes concerning NDs. In the absence of specific laws in support of such a practice, courts have so far taken a highly subjective approach to NDs. In 2007, for example, Wang He An and three other private parties brought an action against the Xinxiang Bureau of Quality and Technical Supervision in response to a requisition ${ }^{140}$ for households to renew their gas meters and pay the subsequent renewal charge. The Xinxiang Municipal Intermediate People's Court refused to accept the case since the document at issue did not target a specific party and could apply repeatedly. It ruled that the requisition was an ND and, accordingly, that it could not adjudicate the matter. Yet, in 2002, a similar case had a different outcome. The Jiangsu Pricing Bureau published an approval ${ }^{141}$ to validate a request by the Nanjing Municipal Public Utilities Bureau to adjust transport fares. By introducing the use of a smart payment card, the Nanjing Municipal Public Utilities Bureau proposed to charge the same fare for passengers regardless of their age. Chen Zhi Chung, one of the many card users, brought an action against the Jiangsu Pricing Bureau to challenge the legitimacy of the Jiangsu Pricing Bureau's approval for the new fare system given that the Jiangsu Pricing Bureau was in a contractual relationship with the card company, which suggested a potential conflict of interests. Though the approval at issue was presented in a similar format to that of the requisition in Wang He An's action, the court accepted the case. It interpreted the approval as a document that cannot be applied more than once on the same passenger and was, therefore, a piece of law rather than an ND. However, the approval can also be interpreted as an ND since it can be applied repeatedly. In fact, the approval applies every time a passenger pays any fare under the new fare system. ${ }^{142}$ Hence, it

${ }^{135}$ National People’s Congress, ‘中华人民共和国地方各级人民代表大会和地方各级人民政府组织法 2004 [No 30] (Organic Law of the Local People's Congresses and Local People's Governments of the People's Republic of China 2004)’ (27 October 2004) art 59(1); Standing Committee of the National People’s Congress, ‘全国人大常委会关于修 改《中华人民共和国地方各级人民代表大会和地方各级人民政府组织法》、《中华人民共和国全国人民代表大 会和地方各级人民代表大会选举法》、《中华人民共和国全国人民代表大会和地方各级人民代表大会代表法》

的决定) [No 33] (Decision of the Standing Committee of the National People's Congress on Amending the Organization Law of the People's Republic of China for Local People’s Congresses at All Levels and Local People’s Governments at All Levels, the Election Law of the People's Republic of China for the National People's Congress and Local People's Congresses at All Levels, and the Law of the People's Republic of China on Deputies to the National People’s Congress and Local People’s Congresses at All Levels’ (29 August 2015).

136 Supreme People’s Court, ‘最高人民法院关于执行《中华人民共和国行政诉讼法》若干问题的解释 [No 8] (Supreme People’s Court's Explanation on that State’s Method for Handling Documents of Administrative Units)’ (8 March 2000) art 3.

137 ibid.

138 PRC Administrative Litigation Law (2014) art 13(2).

139 ibid art 5.

${ }^{140}$ Xinxiang Bureau of Quality and Technical Supervision, ‘关于采取强制措施推进超期燃气表更换工作的报告的答

复函 [No 4] (Response to the Report on the Compulsory Measures for Promoting the Changing of Gas Meters)’ (19 February 2005).

141 Jiangsu Pricing Bureau, ‘关于公交票价改革的批复 [No 276] (Approval for the Adjustment on Fare)’ (27 August 2002).

${ }^{142}$ Zhang Min, 'Judicial Practice of the Normativity of Administrative Litigation Rules - Using Normative Documents as Example (从司法实践看行政诉讼法规则的规范性问题——以其他规范性文件为视角)’ (2011) 21 (3) Journal of Jinan University (Social Science Edition) 89. 
probably was inappropriate for the court to adjudicate the matter. These cases demonstrate the inconsistent approach taken by PRC courts to the interpretation of NDs. Such inconsistent interpretations reveal the problem of relying solely on the Administrative Litigation Law to secure the right of PFTZ investors regarding any disputes concerning NDs, such as the Negative List, before the PFTZ Court.

A recent amendment to the Administrative Litigation Law is unlikely to solve the problem that the ND status of the Negative List presents to PFTZ investors. The amendment only allows courts to accept disputes concerning NDs as long as the challenge is to its 'legality'. ${ }^{143}$ Therefore, PFTZ investors may still face difficulty in putting their case to the PFTZ Court if they concern matters other than the legality of the Negative List, such as the interpretation of a specific clause or a decision made pursuant to the Negative List. These matters would likely remain outside the scope of judicial jurisdiction of the PFTZ Court.

\subsection{The Decision}

The Decision ${ }^{144}$ can also be the cause of disputes between PFTZ investors and the PRC because it too has an unclear legal status, as the article discusses below. In order to create an attractive environment for foreign investment in the PFTZ, while at the same time avoiding an extensive reform to the legal system of the PRC, the PRC government took action in two respects. First, by way of the Negative List, the Shanghai Municipal People's Government and, subsequently, the State Council dispensed PFTZ investors with the need to obtain government approval except for limited investments. Secondly, by way of the Decision, the State Council suspended the implementation inside the PFTZ of four national laws, namely, the Law of the People's Republic of China on Foreign-funded Enterprises 2000, Law of the People's Republic of China on ChineseForeign Equity Joint Ventures 2001, Law of the People's Republic of China on Chinese-Foreign Contractual Joint Ventures 2000, and Law of the People's Republic of China on the Protection of Investments of Taiwan Compatriots 1994. These laws require joint venture agreements with foreign parties as well as foreign-funded enterprises to obtain government approval, ${ }^{145}$ a requirement that is contrary to the PFTZ's goal to create an internationalised business-friendly environment.

The State Council announced the Decision with the authorisation of the Standing Committee of the National People's Congress (SCNPC). ${ }^{146}$ In the absence of relevant 'national laws' (that is, laws enacted and amended by the NPC and/or SCNPC), ${ }^{147}$ the State Council can be authorised to make administrative regulations with respect to certain matters that would have been under the legislative power of the NPC or SCNPC. ${ }^{148}$ The Decision concerns a 'foreign trade system', ${ }^{149}$ a matter that should be governed by laws to be enacted by the NPC and/or SCNPC or by administrative regulations to be made by the State Council pursuant to the Legislation Law, the law that regulates

\footnotetext{
143 PRC Administrative Litigation Law (2014) art 6.

${ }^{144}$ Standing Committee of the National People's Congress of the People's Republic of China (n 13).

145 State Council, ‘中华人民共和国中外合资经营企业法实施条例 2014 [No 648] (Regulation on the Implementation of the Law of the People’s Republic of China on Chinese-Foreign Equity Joint Ventures 2014)’ (19 February 2014) art 5; State Council, ‘中华人民共和国中外合作经营企业法实施细则 2014 [No 648] (Regulation on the Implementation of the Law of the People's Republic of China on Chinese-Foreign Contractual Joint Ventures 2014)’ (19 February 2014) art 5; State Council, ‘中华人民共和国外资企业法实施细则 2014 [No 648] (Regulation on the Implementation of the PRC Wholly Foreign Owned Enterprises Law 2014)’ (19 February 2014) art 6; Standing Committee of the National People’s Congress, ‘中华人民共和国台湾同胞投资保护法 1994 [No 20] (Law of the People’s Republic of China on the Protection of Investments of Taiwan Compatriots 1994)’ (5 March 1994) art 8.

146 Standing Committee of the National People’s Congress (n 13).

${ }^{147}$ PRC Legislation Law (2015) art 9.

148 ibid art 8.

149 ibid art 8(ix).
} 
law-making procedures in the PRC. However, the SCNPC had already legislated with respect to this matter through the four national laws that the Decision suspends. The Decision, therefore, contravenes the Legislation Law ${ }^{150}$ and cannot qualify as a piece of authorised legislation. Such uncertainty in legal status has significant implications for PFTZ investors because, if the Decision does not qualify as a piece of authorised legislation, the only other legal instrument that secures preferential treatment for PFTZ investors is the Negative List, which is no more than an ND. More importantly, the Decision provides that, if the suspension that it introduces fails to attract foreign investment to the PFTZ over the course of its implementation period between 2014 and 2017, the four national laws in question shall resume their effect in the PFTZ. Hence, the Decision, without a proper legal status and a long-term plan for the application of preferential treatment, can cause disputes between PFTZ investors and the PRC, such as about the period during which the Negative List shall remain effective. Ultimately, it does not reconcile the need to promote and protect foreign investment in the PFTZ with the need to preserve the pre-existing regulatory regime across the whole of the PRC.

\subsection{The Management Method}

The Management Method ${ }^{151}$ provides that the settlement of disputes between PFTZ investors and the PRC should be done with reference to the Administrative Reconsideration Law and Administrative Litigation Law. This general provision gives rise to several issues. First, it does not specify the preconditions that PFTZ investors must meet before they can apply for an administrative review or initiate administrative litigation proceedings if they disagree with certain decisions made by the relevant authorities regarding their business operation inside the PFTZ. The Administrative Reconsideration Law only states that, if the 'relevant provisions of laws or regulations' ${ }^{152}$ so require, parties shall obtain an administrative reconsideration from the relevant reviewing body prior to the initiation of administrative litigation proceedings. The language of this provision is inconclusive and makes no reference to the laws and measures that the parties must consult. Moreover, the Administrative Reconsideration Law ${ }^{153}$ does not assist PFTZ investors since the Negative List is a ND and, accordingly, it is outside the scope of application of the provision. In the absence of additional provisions to compensate for the fact that, under the Administrative Litigation Law, ${ }^{154}$ the courts cannot accept disputes concerning NDs, the Management Method leaves PFTZ investors with one option only: to apply for an administrative reconsideration if they want to challenge any decision involving the Negative List, for example, any management decisions or measures taken by the PFTZ Management Committee. Such a limitation is significant because an administrative reconsideration can only be successful if it satisfies what are perfectly ambiguous criteria, such as an 'erroneous application of law' ${ }^{155}$ or a 'obvious inappropriateness of the specific administrative act'. ${ }^{156}$ Without a careful revision of the criteria to assess the degree of inappropriateness, the Administrative Reconsideration Law gives the reviewing body excessive discretion over statutory interpretation and may, therefore, not provide effective protection to PFTZ investors.

Secondly, although the Management Method empowers the PFTZ Management Committee to make decisions on administrative penalties in relation to a range of matters, it only vaguely requires such decisions to be made by reference to 'relevant laws, regulations and rules' ${ }^{157}$ of different government departments. Without a clear indication of the laws and measures to which the PFTZ

\footnotetext{
150 ibid art 9.

151 Shanghai Municipal People’s Government (n 6) art 36.

152 PRC Administrative Reconsideration Law (2009) art 16.

153 ibid 7.

154 PRC Administrative Litigation Law (2014) art 13(2).

155 PRC Administrative Reconsideration Law (2009) art 28(3)(b).

156 ibid art 28(3)(e).

157 Shanghai Municipal People’s Government (n 6) app 3.
} 
Management Committee must refer to before it can issue an administrative penalty, the Management Method confers on the PFTZ Management Committee excessive discretion in the exercise of its authority and leaves PFTZ investors in a state of legal uncertainty.

The Management Method does not establish an effective settlement mechanism for handling disputes between PFTZ investors and the Management Committee. In order to enhance its effectiveness, at least five modifications are necessary. One, the mechanism should prescribe the circumstances in which a party could apply for an administrative reconsideration or initiate administrative litigation proceedings, particularly for parties who want to challenge decisions made under the Negative List, an ND. Two, the mechanism should make reference to the laws and measures that guide the Management Committee in the issuance of administrative penalties. Three, the mechanism should shorten the time limit applicable to the reviewing body in the interest of a more efficient dispute management system. Four, the mechanism should allow the commercial activities that are the subject of the dispute to continue while the applicant awaits the decision. Fifth, the mechanism should state the basis for which recourse against the decisions of the Management Committee could be made. With the introduction of these modifications, the dispute settlement mechanism would be likely to manage disputes more effectively as it would be taking the natural constraints of PFTZ investors into account and, in turn, ensure the proper functioning of the PFTZ.

\section{Solutions to the Problem of Legal Uncertainties as a Cause of Investment Disputes}

Even though the PFTZ, like any other free trade area, is sure to give rise to countless investor-state disputes, the PRC has given little regard to the legal uncertainties that affects the PFTZ. Through an interpretative analysis of a select series of legal instruments that regulate the functioning of the PFTZ, this article has shown that legal uncertainty can indeed cause disputes between PFTZ investors and the PRC. This section of the article proposes three solutions to the problem of legal uncertainty. The first proposal is to specify the test to assess the degree of connection with the PFTZ as the criterion to determine the scope of jurisdiction of the PFTZ Court and the PFTZ Court of Arbitration (Section 4.1.). The second proposal is to clarify the legal status of the two most significant legal instruments to the functioning of the PFTZ, namely, the Negative List and the Decision (Section 4.2.). The third proposal is to reform the dispute settlement mechanism of the PFTZ under the Management Method (Section 4.3.).

\subsection{Rational Connection as the Test for Judicial and Arbitral Jurisdiction}

Arguably, ${ }^{158}$ the Law of the People’s Republic of China on Choice of Law for Foreign-related Civil Relationships (LFCR) ${ }^{159}$ can clarify the ambiguity of the phrase - 'connected with' 160 - in the rules for deciding the justiciability of the PFTZ Court (Justiciability Rules) ${ }^{161}$ and the Shanghai International Arbitration Rule 2014, ${ }^{162}$ which determines the scope of the jurisdiction of the PFTZ Court and PFTZ Court of Arbitration. Resort to interpretation by analogy, however, cannot assist in the management of the particular types of dispute likely to arise between PFTZ investors and the

\footnotetext{
${ }^{158}$ Shu Hai, 'Opinions on Legal Protection for the Shanghai Free Trade Zone (关于自贸区司法保障的几点意见)' (2013) <http://www.mjshsw.org.cn/shmj2011/node713/u1ai1769548.html> accessed 30 January 2017.

159 Standing Committee of the National People’s Congress, ‘中华人民共和国涉外民事关系法律适用法 [No 36] (Law of the People’s Republic of China on Choice of Law for Foreign-related Civil Relationships)’ (28 October 2010).

${ }^{160}$ Institute of China Free Trade Zone Law (East China University of Political Science and Law), 'Research on the Judicial Protection Mechanism of the China (Shanghai) Pilot Free Trade Zone (上海自由贸易试验区的司法保障机制
}

问题研究)' (2015) <http://ftz.ecupl.edu.cn/index.php?c=article\&id=231> accessed 30 January 2017.

161 Shanghai Municipal People’s Government (n 96).

162 Shanghai International Arbitration Rules (2014) art 8. 
PRC. Under the LFCR, a matter involves foreign elements if, either one or more of the parties to the dispute reside 'outside' the PRC; ${ }^{163}$ or the property that is the subject of the dispute is 'outside'164 the PRC; or the relevant facts that constitute the cause of action have occurred 'outside' ${ }^{165}$ the PRC. On that same rationale, then, the degree of connection necessary under either the Justiciability Rules or the Arbitration Rule 2014 would require either that one or more of the parties to the dispute reside inside the PFTZ; or that the property that is the subject of the dispute is inside the PFTZ; or, that the 'establishment, change or termination' ${ }^{\text {'166 }}$ of the relevant facts that constitute the cause of action have occurred inside the PFTZ.

Such an interpretation fails to take into account the unique aims that these three different sets of rules - the LFCR, Justiciability Rules and the Arbitration Rule 2014 - seek to realise. The aim of the LFCR is to confer on foreign parties better legal protection since, prior to its enactment, the relevant laws and measures applicable to foreign parties in civil actions were scattered ${ }^{167}$ over different pieces of legislation and, thus, could not comprise a systematic ${ }^{168}$ and holistic regime. Accordingly, the aim of the LFCR is to cover a wide range of matters with respect to various aspects of the life and work of foreign parties in the PRC. In comparison, while the aim of the Justiciability Rules and the Arbitration Rule 2014 is also to confer on foreign parties better legal protection, they have a much narrower coverage. Both legal instruments aim to complement the Framework Plan on the functioning of the PFTZ in that it creates a legal environment for foreign investment in the PFTZ that is consistent with international standards.

Hence, the measure of the connection should not only be in terms of a geographical connection with the PFTZ but also in terms of a rational connection with the aim of its rules. Rational connection should then be the dominant criterion to determine whether the PFTZ Court or the PFTZ Court of Arbitration can accept a case. Thus, matters that do not connect rationally with the commercial activities conducted by PFTZ investors should not come before the PFTZ Court or the PFTZ Court of Arbitration. Also, an indiscriminate allocation of cases merely on the basis of their geographical connection with the PFTZ would overburden the PFTZ Court and, subsequently, limit its capacity to settle commercial disputes where time is, usually, of the essence. Consequently, in order to maximise the efficiency of the dispute settlement system of the PFTZ, disputes that do not concern commercial activities in the Applicable Areas should not come before the PFTZ Court or PFTZ Court of Arbitration. At the same time, matters that have no geographical connection with the Applicable Areas should, nonetheless, be open to the PFTZ Court and PFTZ Court of Arbitration as long as they are rationally connected with them. The introduction of this alternative criterion would have significant implications for the functioning of the PFTZ because companies registered inside the PFTZ, unless subject to an express prohibition under the Framework Plan, ${ }^{169}$ have permission to operate their business outside the PFTZ. If a dispute arises as a result of an activity that takes place

\footnotetext{
163 Adjudication Committee of the Supreme People’s Court, ‘最高人民法院关于适用《中华人民共和国涉外民事关 系法律适用法》若干问题的解释 ( - ) [No 24] (Supreme People’s Court's Several Explanations on “Laws on Civil Matters Concerning Foreign Parties”)' (10 December 2012) art 1.

164 ibid.

165 ibid.

166 Shanghai International Arbitration Rules (2014) art 3.

${ }^{167}$ Huang Jie, 'Legislation and Perfection of Applicable Laws of China’s Laws Concerning Foreign Civil Relations (中 国涉外民事关系法律适用法的制定与完善)’ (2011) 29(3) Tribune of Political Science and Law 4.

${ }^{168}$ Liu Shan Shan, 'A Study on the Technical Aspect of Laws on Civil Matters Concerning Foreign Parties (《涉外民 事关系法律适用法》立法技术问题探析)’ (2011) 15(4) Cards World: Economics and Law 91.

169 Shanghai Municipal People’s Government, ‘中国 (上海) 自由贸易试验区投资办事常见问题 (Common Questions on Investment inside the China (Shanghai) Pilot Free Trade Zone)’ (2013) <http://zwdt.sh.gov.cn/shen3hall/zmq/zmq_faq.jsp\#问 5> accessed 30 January 2017.
} 
outside the PFTZ, on the basis of the geographical connection criterion alone, it would likely come before the local court near which the company in question operates its business instead of the PFTZ Court or the PFTZ Court of Arbitration, even when the company is registered in the PFTZ. The same outcome would apply to investments and transactions that involve intangible property, for example, the establishment of an online marketplace or the development of new technology by a company inside the Applicable Areas. The property itself is, obviously, not geographically connected with any location, let alone those areas. Yet, the property is rationally connected with the Applicable Areas since the collective free trade area enabled its creation by precisely the kind of business that they aim to attract, foreign investment. It would be absurd for any of these matters not to come before the PFTZ Court or PFTZ Court of Arbitration and not to benefit from special treatment merely because they cannot display a geographical connection.

An interpretation of the Justiciability Rules or the Arbitration Rule 2014 by reference to the LFCR is inappropriate. In order to decide the justiciability of cases that come before the PFTZ Court or PFTZ Court of Arbitration, their causes of action should accord with the categorisation regulations of the Supreme People's Court. ${ }^{170}$ The rational connection of the cause of action with the PFTZ should be the dominant criterion to decide whether the PFTZ Court or PFTZ Court of Arbitration can hear a case, particularly when intangible property is in question. Geographical connection should remain a complementary criterion when tangible property is in question, for example, in relation to disputes concerning real estate inside the Applicable Areas or disputes between a PFTZ company and its employees. The present, equivocal definition of jurisdiction is inadequate and specific criteria for justiciability are necessary. And if the authority formally adopts such an analogical interpretation of the rules, it would further face potential disputes deriving from ambiguous concepts such as the 'Pudong New Area's economic development' or 'reform of the government systems'. ${ }^{171}$ Given that both the PFTZ and the Pudong New Area are still undergoing significant developments, it is likely that the meaning of such rules would vary from time to time. Therefore, it is essential that the authorities exercise their competence to set out guidelines or procedures for the courts to decide whether a case should be accepted, for example, by consolidating cases that have been previously accepted.

\subsection{Enact the Negative List and the Decision as Laws}

Since the uncertain legal status of the Negative List and Decision can cause disputes between PFTZ investors and the PRC, confirmation of the validity of these legal instruments is urgently necessary. Otherwise, the Negative List, as a ND, and the Decision, as a defective piece of authorised legislation, may have their validity become the subject of disputes even if these disputes actually concern the content, not the validity of the legal instruments. In a worst-case scenario, PFTZ investors may not even be able to bring disputes concerning the Negative List under the Administrative Reconsideration Law. Therefore, these legal instruments should receive due recognition as laws, that is, the authorities should republish them in compliance with the requirements of the Legislation Law. The PRC may refer, for assistance, to similar laws in other jurisdictions, for example, the United States and Singapore. In 1934, the United States enacted the Foreign-Trade Zones Act, which establishes review procedures for administrative decisions. ${ }^{172}$ In 1969, Singapore enacted the Free Trade Zones Act, which contains a mechanism for the review of administrative decisions. ${ }^{173}$ Now that the PFTZ has been in operation for over three years, the time is opportune for either the NPC or SCNPC to reinforce the legal framework of the PFTZ through a

\footnotetext{
${ }^{170}$ Supreme People’s Court, ‘最高人民法院关于印发《民事案件案由规定》的通知 [No 11] (Supreme People’s Court's Notice on Issuing the Regulations on Categorization of Civil Cases)' (1 April 2008).

${ }^{171}$ Shanghai Municipal People’s Government (n 96).

172 Foreign-Trade Zones Act, art 81r.

${ }^{173}$ Free Trade Zones Act, art 13(2).
} 
coherent set of laws and not an unsystematic array of legal instruments to avoid further disputes related to legal status and to enable reviewability by courts.

\subsection{Reform of the PFTZ Dispute Settlement Mechanism}

Even though the Management Method allows PFTZ investors to initiate administrative litigation proceedings, their right to have disputes come before the PFTZ Court is in question since this court contravenes the judiciary laws of the PRC. As the court of what is a free trade area, the PFTZ Court's main responsibility is to handle the various matters that the business of PFTZ investors naturally brings up. However, under the Supreme People's Court's regulation, only intermediate or higher courts can conduct the hearing of administrative cases concerning 'international business transactions'. ${ }^{174}$ This procedural requirement is applicable to all administrative review cases that involve international trade, for example, the sale and purchase of goods, services, or intangible property such as intellectual property. ${ }^{175}$ Therefore, as a 'basic court', ${ }^{176}$ the PFTZ Court cannot handle the kind of administrative disputes that arise out of foreign investment activities since most administrative decisions by the PFTZ Management Committee involve elements of international business transactions, such as the approval of foreign ventures inside the PFTZ. ${ }^{177}$ The rules of civil procedure compel the adjudication of these administrative disputes by the Shanghai No 1 Intermediate Peoples' Court together, of course, with any other matters that arise out of activities outside the PFTZ, this restriction makes the efficient management of PFTZ cases impossible and deprives the PFTZ Court of any practical use.

The dispute settlement mechanism under the Management Method needs substantial reform before it can provide real assistance to PFTZ investors. However, the PFTZ should not only rely on the administrative review and litigation mechanisms of the PRC. It should also offer arbitration as an alternative settlement mechanism for disputes between PFTZ investors and PFTZ authorities such as the Management Committee in the interest of greater operational efficiency and flexibility. Disputes between foreign investors and the state have become very common with the proliferation of Bilateral Investment Treaties (BITs) in recent years. In order to ensure an efficient management of these disputes, most BITs contain a clause that provides for arbitration either with the International Centre for Settlement of Investment Disputes (ICSID) or under the rules of the United Nations Commission on International Trade Law (UNCITRAL), ${ }^{178}$ an option which is already available to PFTZ investors should they choose arbitration for the settlement of private-private disputes. $^{179}$

Arbitration is in high demand by foreign investors everywhere in the PRC, especially by those who are not familiar with the country's civil litigation proceedings. Foreign investors tend to have more confidence in ICSID, UNCITRAL and such other alternative conflict resolution mechanisms than in the courts of a country that is notorious for its lack of judicial independence. ${ }^{180}$ ICSID, in particular, is able to offer an effective 'alternative to the courts and administrative tribunals of the host

\footnotetext{
${ }^{174}$ Supreme People’s Court, ‘最高人民法院关于审理国际贸易行政案件若干问题的规定 [No 27] (Supreme People’s Court's Regulation on adjudication of Administrative cases involving International Business Transaction) (27 August 2002) art 5.

175 ibid art 1.

${ }^{176}$ Huang Jie, 'Research on China (Shanghai) Pilot Free Trade Zone Dispute Resolution (中国(上海)自由贸易试验区

争端解决机构研究)' [2014] 4 Research on One Country Two Systems 170.

177 Shanghai Municipal People’s Government (n 6) app 1-3.

${ }^{178}$ Markus Burgstaller and Charles B Rosenberg, 'Challenging International Arbitral Awards: To ICSID or Not to ICSID’ (2011) 27(1) Arbitration International 92.

${ }^{179}$ Shanghai International Arbitration Rules (2014) art 5.

${ }^{180}$ He Weifang, In the Name of Justice (Brookings Institution Press 2012) 13.
} 
state', ${ }^{181}$ since, unlike UNCITRAL awards, ICSID awards are, generally, not appealable ${ }^{182}$ before the domestic courts. ICSID creates a self-contained international system, albeit controversially subject to ad hoc annulment committees.

Some international investment actors may question the use of arbitration in handling investor-state disputes. In 2011, for example, Australia's Department of Foreign Affairs and Trade announced that the Australian Government would no longer insert 'investor-state dispute resolution procedures ${ }^{183}$ in its new BITs. The impetus ${ }^{184}$ behind this drastic change of practice came from a challenge by Philip Morris to the Australian Government's restriction on tobacco packaging, a challenge that the American cigarette and tobacco company made through the arbitration mechanism in the BIT between Australia and Hong Kong. Philip Morris initiated arbitral proceedings against the Australian Government on the grounds that the legislation amounts to an 'expropriation' 185 of the company's investment 'due to the substantial deprivation of the intellectual property and goodwill'. ${ }^{186}$ Even though the arbitration tribunal eventually declared that it had no jurisdiction to hear the claim, ${ }^{187}$ the Australian Government remains concerned that investor-state arbitration clauses could risk the implementation of public policy. However, such a risk can be offset by the incorporation of certain contractual clauses, such as a 'general exception provision'188 in the style of Article XX of the General Agreement on Tariffs and Trade (GATT), which provides that the host state's implementation of policy 'necessary to protect human, animal or plant life or health' 189 shall prevail over the compliance of its treaty obligations. Such provisions are not uncommon and similar clauses have been adopted in many BITs, such as Colombia-Japan, ${ }^{190}$ Canada-Thailand, ${ }^{191}$ Canada-Jordan, ${ }^{192}$ and even in some of the earliest BITs of the PRC, for example New Zealand-China. ${ }^{193}$ The insertion of these clauses is likely to protect host states from potential challenges to their domestic policies and would, therefore, neutralise any potential threat to national policies if the PFTZ were to adopt arbitration as a dispute resolution mechanism.

\footnotetext{
${ }^{181}$ Andreas F Lowenfeld, International Economic Law (OUP 2008) 570.

${ }^{182}$ Convention on the Settlement of Investment Disputes between States and Nationals of Other States (opened for signature 18 March 1965, entered into force 14 October 1966) 17 UST 1270, 575 UNTS 159 (ICSID Convention) art 53(1); Michael J Moser, Managing Business Disputes in Today’s China: Duelling with Dragons (Kluwer Law International 2007) 277.

${ }^{183}$ Department of Foreign Affairs and Trade (Australia), 'Gillard Government Trade Policy Statement: Trading Our Way to More Jobs and Prosperity’ (2011) <www.acci.asn.au/getattachment/b9d3cfae-fc0c-4c2a-a3df3f58228daf6d/Gillard-Government-Trade-Policy-Statement.aspx> accessed 30 January 2017.

${ }^{184}$ Matthew Rimmer, 'Trojan Horse Clauses: Investors-State Dispute Settlement' (Submission to Senate Standing Committee on Foreign Affairs Defence and Trade Legislation Committee, Parliament of Australia) (April 2014$) 10$.

185 Philip Morris Asia Limited v The Commonwealth of Australia, PCA Case No 2012-12, Notice of Claim (22 June 2011) para 10(a).

186 ibid.

${ }^{187}$ Permanent Court of Arbitration, 'Philip Morris Asia Limited (Hong Kong) v. The Commonwealth of Australia' (2016) < http://www.pcacases.com/web/view/5 > accessed 30 January 2017.

188 Jürgen Kurtz, ‘Australia’s Rejection of Investor-State Arbitration: Causation, Omission and Implication’ (2012) 27(1) ICSID Review 65, 72.

189 World Trade Organization, Article XXT'

<https://www.wto.org/english/docs_e/legal_e/gatt47_02_e.htm\#articleXXI> accessed 30 January 2017.

${ }^{190}$ Agreement between Japan and the Republic of Colombia for Liberalization, Promotion and Protection of Investment (signed 12 September 2011, not yet in force) art 21.

${ }^{191}$ Agreement Between the Government of Canada and the Government of the Kingdom of Thailand for the Promotion and Protection of Investments (signed 17 January 1997, entered into force 24 September 1998) CTS 1998 No 29, art XXVII (3)(b).

192 Agreement Between Canada and the Hashemite Kingdom of Jordan for the Promotion and Protection of Investments (signed 28 June 2009, entered into force 14 December 2009) art 11.

${ }^{193}$ Agreement between the Government of New-Zealand and the Government of the People's Republic of China on Promotion and Protection of Investments (signed 22 November 1988, entered into force 25 March 1989) 1787 UNTS 186, art 11.
} 
An investor-state arbitration mechanism for the PFTZ would be comparable to other domestic investment laws in which the State consents to arbitrate certain categories of disputes. Thus, if it is to adopt an investor-state arbitration mechanism, the PRC needs to provide the necessary legal framework - through domestic legislation for local courts to enforce either ICSID or UNCITRAL awards - rather than enter into BITs (and other investment treaties), which require reciprocal endorsement. Reciprocity is a principle inherent to BITs, where one state offers 'the subjects of the other certain privileges on the condition that its subjects enjoy similar privileges in the other state'. ${ }^{194}$ Given that the PFTZ operates as a scheme to liberalise domestic trade and to attract foreign investors, BITs would be neither a feasible nor desirable mechanism through which to adopt an investor-state arbitration mechanism. An investor-state arbitration mechanism for the PFTZ would not rely on any reciprocal arrangement but on domestic legislation.

Thus, domestic legislation would be required for PRC courts to enforce either ICSID or UNCITRAL awards. Although the PRC became a party to the New York Convention on the Recognition and Enforcement of Arbitral Awards (New York Convention) in $1986^{195}$ and a party to ICSID in 1993, ${ }^{196}$ a study of the relevant domestic legislation reveals that these seemingly similar awards enjoy vastly different legal status in the legal system of the PRC. For years, a school of thought has argued that treaties are 'directly applicable ${ }^{197}$ in the PRC under the doctrine of 'adoption'. ${ }^{198}$ Adoption dispenses a state with the need to enact specific legislation to 'transform'199 the treaties into domestic laws. In other words, treaties form part of the state's domestic legal framework upon signature. On this argument, parties should be able to enforce their awards in accordance with the Civil Procedural Law, which provides that parties can apply to intermediate people's courts' ${ }^{200}$ for 'recognition and enforcement' ${ }^{201}$ of the award under ICSID or the New York Convention. However, the doctrine of adoption is not consistent with the PRC's current approach to the implementation of international agreements. Generally, a 'reference' ${ }^{202}$ to the treaty is necessary, either in the form of notices or interpretations issued by the Supreme People's Court, ${ }^{203}$ which carry 'legislative' 204 effect. Thus, in 1987, the Supreme People's Court issued a notice by which it stipulated that the New York Convention would enter into force in the PRC on 22 April 1987. ${ }^{205}$ Additionally, it provided an outline for the application of an arbitral award pursuant to the New York Convention. First, it set out the list of requirements ${ }^{206}$ for intermediate people's courts to accept an arbitral award. Secondly, it gave full effect to the New York Convention by confirming

194 Young-Joon Mok, 'The Principle of Reciprocity in the United Nations Convention on the Recognition and Enforcement of Foreign Arbitral Awards of 1958' (1989) 21(2) Case Western Reserve JIL 123, 124-25.

195 Xia Xiaohong, 'Implementation of the New York Convention in China' (2011) 1(1) International Commercial Arbitration Brief 20.

$196 \quad$ World Bank, 'China ICSID Membership' (2014)

$<$ https://icsid.worldbank.org/apps/ICSIDWEB/about/Pages/MembershipStateDetails.aspx?state=ST30> accessed 30 January 2017.

${ }^{197}$ Björn Ahl, Application of International Treaties in China (Springer 2009) 358.

198 ibid.

199 ibid 359.

${ }^{200}$ Supreme People’s Court, ‘最高人民法院关于适用〈中华人民共和国民事诉讼法〉的解释 [No 5] (Supreme People’s Court’s Applicable explanation of the PRC Civil Procedural Law)’ (30 January 2015) art 544.

201 ibid.

202 Ahl (n 197) 362.

203 Standing Committee of the National People’s Congress, ‘全国人民代表大会常务委员会关于加强法律解释工作

的决议 (Standing Committee of the National People’s Congress' Resolution on Strengthening the Interpretation of Laws) (10 June 1981) art II.

${ }^{204}$ Ahl (n 197) 363.

${ }^{205}$ Supreme People’s Court, ‘最高人民法院关于执行我国加入的《承认及执行外国仲裁裁决公约》的通知 [No 5] (Supreme People's Court's Notice on People’s Republic of China’s Implementation of the “New York Convention on the Recognition and Enforcement of Arbitral Awards")' (10 April 1987).

206 ibid 3-5. 
its supremacy over the domestic laws should any 'conflicts' 207 between them arise. This notice continues to reassure foreign parties that they can enforce their UNCITRAL awards ${ }^{208}$ in the PRC.

However, there have been no similar notices or interpretations issued by the NPC, SCNPC, or Supreme People's Court on the application of ICSID. Although the PRC is a party to ICSID, signature of the convention alone cannot give full effect to an ICSID award. The PRC, as a member state, is under an obligation to devise 'legislative or other measures' ${ }^{209}$ to ensure that an ICSID award is treated as 'binding, ${ }^{210}$ and is enforced 'as if it were a final judgment of a court in that State' ${ }^{211}$ Therefore, the enforceability of ICSID awards still hinges on the recognition of ICSID by the PRC through legislative action. To think that ICSID applies automatically, without more, would be an incorrect assumption. Furthermore, under the doctrine of 'Three Supremes', the sovereignty of the Central Government prevails ${ }^{212}$ over its international law obligations and, thus, the impossibility of an unrestricted and unregulated application of treaties inside the PRC regardless of its inconsistencies with domestic laws. Therefore, even though the Civil Procedural Law states that 'applicable international agreements' ${ }^{213}$ prevail over domestic laws, whether a treaty is deemed to be applicable without any relevant domestic legislation remains a highly uncertain question.

Even if the PFTZ were to provide for UNCITRAL arbitration instead of ICSID arbitration, further legislation and clarification would be necessary to enable the enforcement of UNCITRAL awards regarding investor-state disputes. Further to the notice by the Supreme People's Court, the New York Convention applies only to disputes between private investors and is, therefore, not applicable to 'investor-state disputes' ${ }^{214}$ Hence, despite the formal recognition of the New York Convention's effect in the PRC, this express prohibition means that, when it comes to investor-state disputes, foreign parties with UNCITRAL awards are likely to be in the same predicament as parties with ICSD awards. Furthermore, it is possible for the people's court to refuse to enforce an arbitral award if it is in the opinion that it is not in line with the 'social and public interest'. ${ }^{215}$ This power is also embodied in the New York Convention, which states that the recognition and enforcement of an arbitral award may be refused if it is 'contrary to public policy' ${ }^{216}$ of the country. However, given that what constitutes a contravention of social and public interest is an inherently equivocal concept, parties to an arbitration have to be aware of the uncertainty that would surround the enforcement of their arbitral awards. Thus, in order to establish an effective arbitral investor-state dispute settlement mechanism either in accordance with ICSID or the UNCITRAL rules, the Central Government should issue the requisite legal instruments to give effect to these conventions.

\section{Conclusion}

Through an interpretative analysis of the legal instruments that regulate the functioning of the PFTZ - the Framework Plan, the Negative List, the Decision, the Management Method - this article has shown that legal uncertainty can cause investor-state disputes between PFTZ investors and the PRC, for example, the court's reviewability of the Negative List. As a solution to the problem of legal uncertainty, the article has proposed, first, the adoption of rational connection to the PFTZ as

\footnotetext{
207 ibid art 1.

${ }^{208}$ Moser (n 182) 278.

${ }^{209}$ ICSID Convention (n 182) art 69.

210 ibid art 54.

211 ibid.

${ }^{212}$ Liao Fuyao, 'Preliminary Discussion on Application of International Treaties in China (论国际条约在中国的适用)' (2004) 1 Journal of Tianshui College of Administration 50.

213 PRC Civil Procedural Law (2012) art 260.

214 Supreme People’s Court (n 205) art 2.

215 PRC Civil Procedural Law (2012) art 274.

${ }^{216}$ United Nations Convention on the Recognition and Enforcement of Foreign Arbitral Awards (opened for signature 10 June 1958, entered into force 7 June 1959) 330 UNTS 38 (New York Convention) art V(2)(b).
} 
the test for jurisdiction of the PFTZ Court and the PFTZ Court of Arbitration respectively; secondly, the enactment of the Negative List and the Decision as laws in order to clarify their legal status; and, thirdly, a reform of the PFTZ dispute settlement mechanism under the Management Method into an arbitral system. These proposals should minimise ambiguities in the interpretation of PFTZ laws, enhance the efficiency of the PFTZ Court and PFTZ Court of Arbitration, and ensure PFTZ investors an effective legal mechanism for the settlement of their disputes with the PRC. Undoubtedly, these proposals demand significant legal amendments, likely difficult to implement. However, these amendments should lay a solid legal foundation for the sustainable development of the PFTZ and other free trade zones currently developing in the PRC with the assurance that they would be rigorously monitored since they would only apply inside the PFTZ.

The real problems, however, are those whose solutions would imply changes that would affect the whole country, such as the establishment of an effective international arbitration mechanism in accordance with the conventions that the PRC has entered into. These changes would potentially affect the entire governance structure since they would affect the government's degree of control over affairs involving both domestic and foreign parties. These changes raise a question that ultimately relates back to the sovereignty of the PRC, which has always held a supreme status above and regardless of changes in people and time. In the end, the question is whether the PRC is ready to give real effect to the 'reform and opening-up' ${ }^{217}$ that it has promised in the PFTZ Framework Plan for the long-term development of the PFTZ and, more widely, the PRC. While the various recent notices ${ }^{218}$ of the State Council extending PFTZ policies beyond the PFTZ may be indicators of the PRC's willingness to implement nationwide reforms, the extent of those reforms still awaits further clarification. Until then, the PFTZ and its investor-state dispute settlement system will remain an experiment, an uncertain experiment.

\footnotetext{
217 State Council (n 5) pt 4.

218 State Council, ‘国务院关于推广中国(上海)自由贸易试验区可复制改革试点经验的通知 [No 65] (Notice of the State Council on the Wide_Application of Replicable Reform Experience from the Pilot Programs in China (Shanghai) Pilot Free Trade Zone)’ (21 December 2014); State Council, ‘国务院关于做好自由贸易试验区新一批改革试点经验
}

复制推广工作的通知 [No 63] (Notice of the State Council on the Further_Application of Replicable Reform Experience from the Pilot Programs in China (Shanghai) Pilot Free Trade Zone)' (2 November 2016). 